\title{
Examining the Use of Social Media in Building a Student Personal Brand and the Impact of Demographics
}

\author{
Tulay Girard \\ Penn State Altoona \\ Musa Pinar \\ Valparaiso University
}

\begin{abstract}
Personal branding has recently gained interest as employer requirements and recruitment practices have been transformed with advancements in technology. Social media platforms have made personal branding efforts both easy and challenging. Prior research pointed out that college students and graduates entering the job market need to understand the importance of current technology tools and utilize them in building their personal brand and searching for jobs. However, empirical research on the topic is very limited. To respond to this void, this study examines students' perceptions of their efforts for building their personal brands using social media. Data were collected using an online survey at two universities in the U.S. The findings reveal that students' perceptions of their efforts in building their personal brands differ by their use of social media platforms and demographics. Practical implications are discussed.
\end{abstract}

Keywords: student personal branding efforts, social media use

\section{INTRODUCTION}

The concept of personal branding has recently become the focus of researchers as the expectations, requirements, and recruitment processes of potential employers have been transformed with the advancements in technology, especially with social media accounts and search engines (LeBlanc, 2018; McCabe 2017). In a Forbes article, Castrillon (2019) points out that a job applicant will be very likely to be searched in search engines and social media before a job interview. Personal branding became an important concept due to the ability to present oneself easily to others through social media sites. Cultivating a personal brand for students, entrepreneurs, job candidates, and employees has become more important than ever (Spencer, 2020).

Hood et al. (2014) pointed out that college students and graduates entering the job market need to understand the importance of current technology tools and utilize them in building their personal brand and searching for jobs. Identifying the core attributes from literature of multi-disciplines, Gorbatov et al., (2018, p. 6) proposed a definition of personal branding as "a strategic process of creating, positioning, and maintaining a positive impression of oneself, based on a unique combination of individual characteristics, which signal a certain promise to the target audience through a differentiated narrative and imagery." They also defined personal brand as "a set of characteristics of an individual (attributes, values, and beliefs, etc.) 
rendered into the differentiated narrative and imagery with the intent of establishing a competitive advantage in the minds of the target audience" (p. 6).

As the recently published studies illustrate, the research examining the extent of student efforts using the current technology tools in building their personal brand is limited (Ollington et al., 2013; Gershon 2014), especially in the area of utilizing social media tools (Girard et al., 2020; Vitelar, 2019). In response to the need for empirical research to understand students' perceptions and efforts to build their personal brand using social media, this study aims to offer further insights to narrow the gap by examining students' perceptions of their efforts for building their personal brands using social media.

\section{BACKGROUND}

As a recent phenomenon, the concept of personal branding has gained interest in different marketing areas and contexts, such as celebrities (Rein et al., 2005), politicians and and political parties (Manai and Holmlund, 2014), and athletes (Arai et al., 2013) to promote self-identity and/or advance their careers. Khedher (2015) traces the concept to the development of positioning strategy in the book authored by Ries and Trout (1986). Several studies (i.e., Burnison, 2018; Girard et al., 2020; Korach, 2015; NACE, 2018) have identified and examined the attributes relevant to student personal branding.

Researchers have recognized that the key factor of personal success is understanding the importance of and building a personal brand (Rampersad, 2008; Hood et al., 2014; Girard et al., 2020). Published studies have focused on building a student personal brand during the college years (Ilies, 2018; Vitelar, 2019; Parrott, 2019; LeBlanc, 2018; Girard et al., 2020), creating and building personal brands with the user generated content (Kucharska, 2017; Kucharska and Confente, 2017; Labrecque et al. 2011; McCorkle and Payan, 2017), using social media to promote personal brands (Parrott, 2019; McCorkle and Payan, 2017; Sihi and Lawson, 2018; Vitelar, 2019), and promoting personal brands through social networking (Harris and Rae, 2011; Morris, 2009; McCorkle and Payan, 2017).

Recently, personal branding has become important for college students when they seek successful career opportunities in the job market upon graduation in the current competitive environment (Girard et al., 2020). In a study that investigated what employers look for in job applicants' personal brands and what communication tools business students should incorporate into building their personal brands, Hood et al. (2014) identify not only a list of personal branding attributes from the literature but also the traditional tools of personal branding such as resumes, cover letters, phone and in-person contacts in addition to the online tools such as social media sites including Facebook LinkedIn, Twitter and [personal] web sites, professional bios, searches and employer web sites (Poeppelman and Blacksmith, 2014). Vitelar (2019) points out that social presence sites like Facebook, Instagram, LinkedIn, [Twitter, and Pinterest] characterize high levels of self-presentation and self-disclosure due to the ability to post photos, video and audio files, and microblog content. This type of content creates an image that is consistent with the user's personal brand identity (Kaplan and Haenlin, 2010) reflecting one's background, philosophy, lifestyle, and passions (Wilson and Blumenthal, 2008).

A recent survey conducted in April 2020 by YPulse to understand the impact of Covid-19 on social media use by Gen $\mathrm{Z}$ and Millennials reveals that Instagram is the most used platform by youth between the 13 and 25 years old. Facebook is the top used platform by the age group between 26 and 37 years old. The study confirms an increasing shift in the use of social media platforms like YouTube, TikTok, and Snapchat due to the pandemic. The studies conducted by market research firms have typically reported statistics on the use of social media for social reasons, but not specifically on the use of social media for building a personal brand.

Because social media has become very important for creating personal brands in the digital era, it has become essential that students have a strong social media presence to create and maintain a strong personal brand. In a qualitative study, Kleppinger and Cain (2015) stress that students must be familiar with various social media platforms and actively manage their profiles. They must also minimize any potential negative and controversial photos, content, and poor grammar (LeBlanc, 2018). LeBlanc (2018) emphasizes the importance of taking advantage of networking opportunities to build relationships and elevate one's own 
personal branding. Similarly, Kleppinger and Cain (2015) state that social media allows professionals to connect to past, current, and potential colleagues. This is consistent with the suggestion to use social networking and networking opportunities for building relationships and personal branding (Kleppinger and Cain, 2015; LeBlanc, 2018).

Stating that the study of personal branding lacks empirical research, Gujarathiu and Kulkarni (2018) examined the perceptions of 51 management graduates concerning their intentions, attitude, and the institutional support for implementing their personal brand. They found that graduates' intentions positively correlated with their efforts to secure a dream job, and that significant differences existed in their perceptions of institutional support they received in their management MBA program. Furthermore, Parrott (2019) points out that students often are viewed as consumers of university products, expected to manage self-image, and promote themselves to the job market. Focusing on LinkedIn, McCabe (2017) suggests social media marketing strategies for career advancement and introduces the job search cycle and the job search model as two social media tools to better understand how LinkedIn works.

Ward and Yates (2013) emphasize the importance of integrity, authenticity, and consistency in developing personal brands both online and offline, especially through e-professionalism. Expanding the topic, Kucharska and Confente (2017, p. 162) present a literature review and conclude that "building a personal brand in the network economy is one of the key factors influencing personal position in valued networks," which is a new desired skill. Harris and Rae (2011) also stress the importance of social networking for accessing career opportunities or being left behind.

Drawing from the suggestions, conceptualizations, and identified gaps in the literature that mostly focus on students' use of offline and online tools including social media, this study develops measurements and examines the perceptions of college students' efforts in general and using their social media presence in building their personal brands.

\section{Research Objectives}

This study examines the student perceptions of social media in helping students build their personal brand and the role and use of various social media for building student personal brand. The specific objectives are to determine:

1. The most used social media platforms by students for personal branding.

2. Students' perceptions of their social media efforts for building their personal brands and the perceptions of their personal branding efforts in general.

3. The differences in students' perceptions of their personal branding efforts based on the social media platforms they use.

4. If various personal branding efforts are impacted by student demographics.

5. If the social media platform use differs by student demographics.

The following sections include the Methodology, Results, Discussions and Implications of the findings for student personal branding, and the Limitations and Suggestions for Future Research.

\section{METHODOLOGY}

To accomplish the research objectives (ROs), drawing from the literature a survey instrument was developed to include five statements to measure students' perceptions of personal branding efforts using social media (Kaplan and Haenlin, 2010; Kleppinger and Cain, 2015; LeBlanc, 2018; Harris and Rae, 2011; Morris, 2009; McCorkle and Payan, 2017) and three statements to measure students' perceptions of personal branding in general (Gujarathiu and Kulkarni, 2018; Girard et al., 2020). In the introduction paragraph, a brief and simple definition of the concept was provided, "Personal Branding is defined as an ongoing process of developing and maintaining a reputation and impression of an individual, group, or organization" (Henderson, 2019). The survey also included students' use of various social media platforms in building their personal brand, which are Instagram, LinkedIn, Facebook, Twitter, Pinterest and other with a blank space to specify. Lastly, demographic questions captured gender, class standing, age, major, whether the respondents were International students, and class standing. 
The statements related to students' use of social media for building personal branding were measured with a 5 -point Likert scale ranging from $1=$ strongly disagree to $5=$ strongly agree. The use of social media questions was measured with nominal scale as "Yes / No".

The survey instrument was initially pretested with expert academicians on branding and survey development. After receiving valuable suggestions for the survey questions, the improved survey instrument was pretested with students who are the target population of the study. The pretests provided further insights for improvement of the questions and face validity of the statements to be included in the final survey (Churchill and Iacobucci, 2005).

\section{Sampling and Data Collection}

The data were collected from students at a private university in mid-western United States and at a large U.S. public university using a link to the online survey built in Qualtrics. Because the students' perceptions are the focus of this study, they comprise the target population. At the public university, the survey link built in to an email invitation was sent to all students' email addresses and was advertised in biweekly newsletters sent through the Career Services Office. Additionally, a few professors in the business field distributed the survey link and invitation to the students enrolled in their courses. An incentive to participate in the survey for personal branding was offered for a random chance to win one of four $\$ 50$ gift cards.

At the private university, the survey link was distributed by the faculty who teach in different disciplines including business, engineering, art \& science, nursing, and others. During Covid-19 pandemic, the data collection method was deemed the most feasible way to obtain a sample of students from the most fields of study. In two weeks, this method produced a total of 161 usable responses for analysis, 94 responses from the public university and 67 responses from the private university. The selected profiles of respondents show that $48.7 \%$ of respondents are male, $51.3 \%$ are female, and $3.8 \%$ are freshman, $36.7 \%$ are sophomore, $21.5 \%$ are junior and $38 \%$ are senior, and $88.6 \%$ are domestic students and $11.4 \%$ international students. The average age of the respondents is 20.8 years.

\section{RESULTS}

In order to identify the social media platforms most used by students for personal branding (RO1), percentages of the usage of each social media platform for personal branding were calculated in SPSS. Figure 1 indicates that the major platforms students use from the most to least include Instagram, LinkedIn, Facebook, Twitter, and Pinterest. Students also used other platforms such as TikTok, Snapchat, WeChat, Handshake, and VSCO.

FIGURE 1

\section{SOCIAL MEDIA PLATFORMS USED FOR PERSONAL BRANDING}

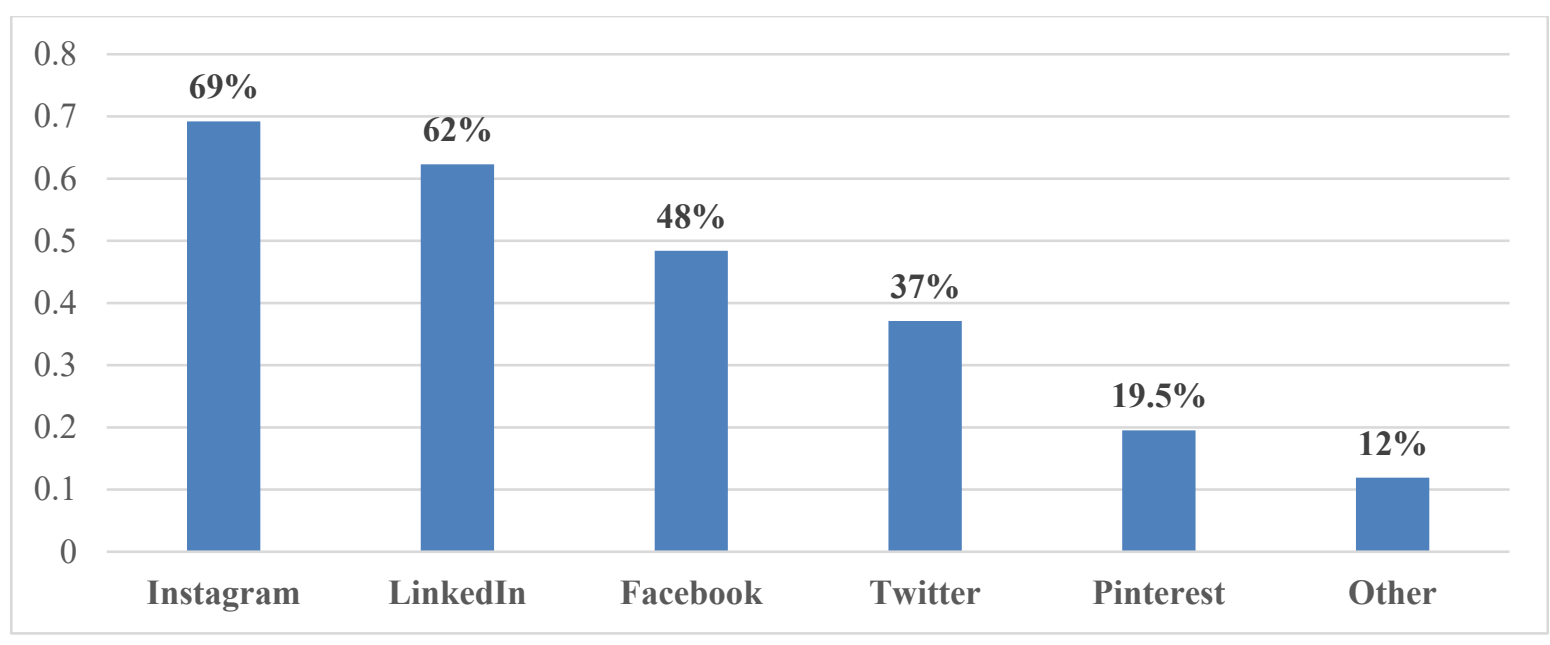

10 Journal of Marketing Development and Competitiveness Vol. 15(3) 2021 
For RO2, five statements measured students' perceptions of students' personal branding efforts through the use of social media. The highest agreement response mean value was 3.78 for the statement, "I make sure that my personal brand on social media reflects a consistent image of me" on a 5-point agreement scale, followed by 3.43 for "I actively manage my personal branding on social media." Figure 2 presents the mean values of students' perceptions of their social media and general personal branding efforts.

Based on the One-sample T-test results, while the two statements were significantly higher than the mid-point 3 at $\mathrm{p}<.01$, the third statement, "I have used social media presence to elevate my own personal branding with a mean value 3.25 was also significantly higher than the mid-point 3 at $p<.05$ level. The mean values of the other two statements "I have taken advantage of the networking opportunities on campus or online" and "Most social media platforms are not good places to create a personal brand" were not significantly different than the mid-point 3 on a 5-point agreement scale ( $p>.05)$. The non-significant results indicate that students need to take advantage of the networking opportunities on campus and/or online, and consider social media platforms as places to create and build their personal brands.

\section{FIGURE 2}

\section{EVALUATIONS OF PERSONAL BRANDING EFFORTS}

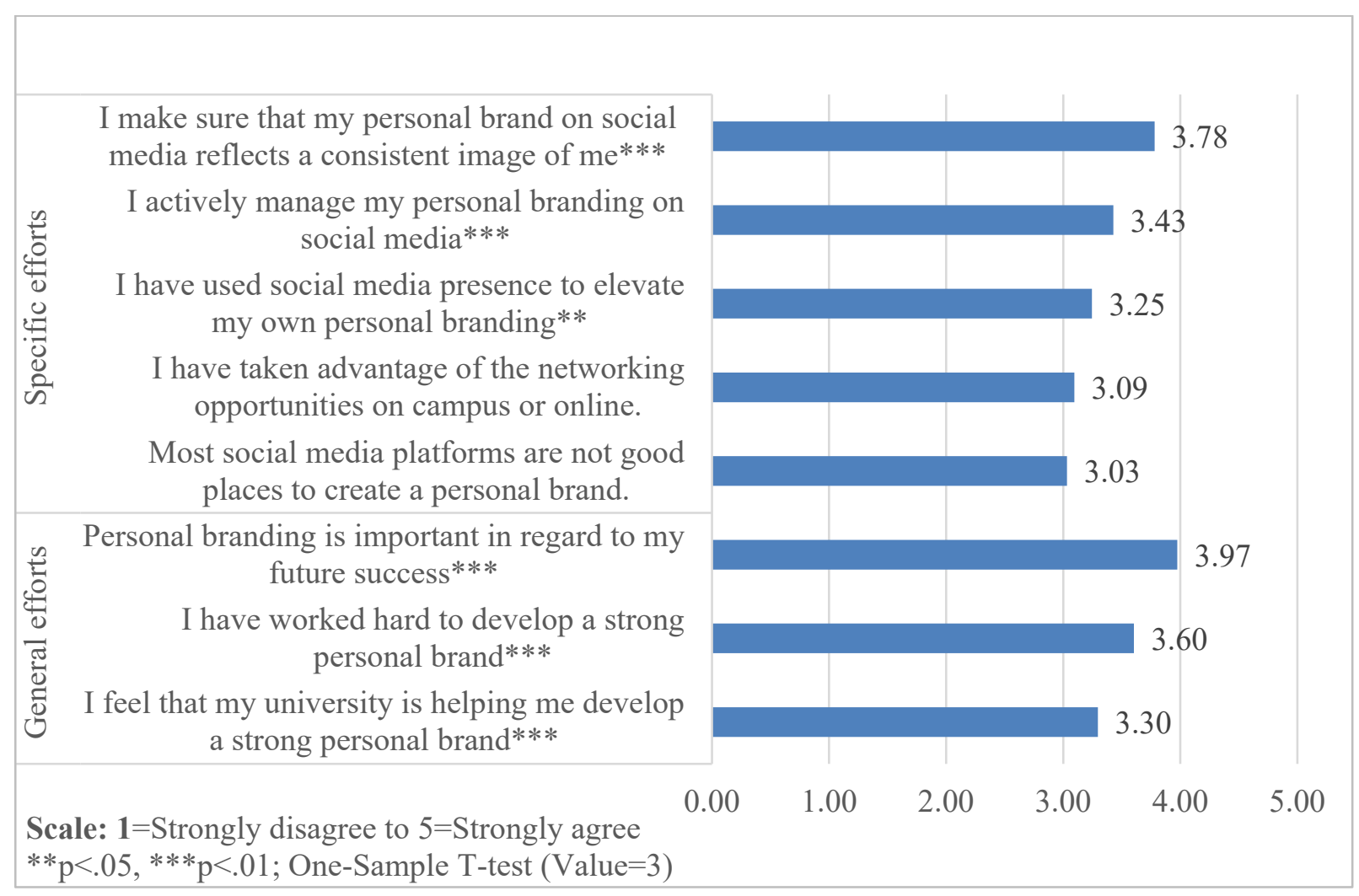

Figure 3 shows the valid percents of agreement levels. All of the five statements related to social media use for personal branding efforts were between 3 (neutral) and 4 (agree) on a 5-point agreement scale, which indicate that there is still room for improvement. 


\section{FIGURE 3 \\ STUDENT PERCEPTIONS OF THEIR PERSONAL BRANDING EFFORTS ON SOCIAL MEDIA (IN PERCENT)}

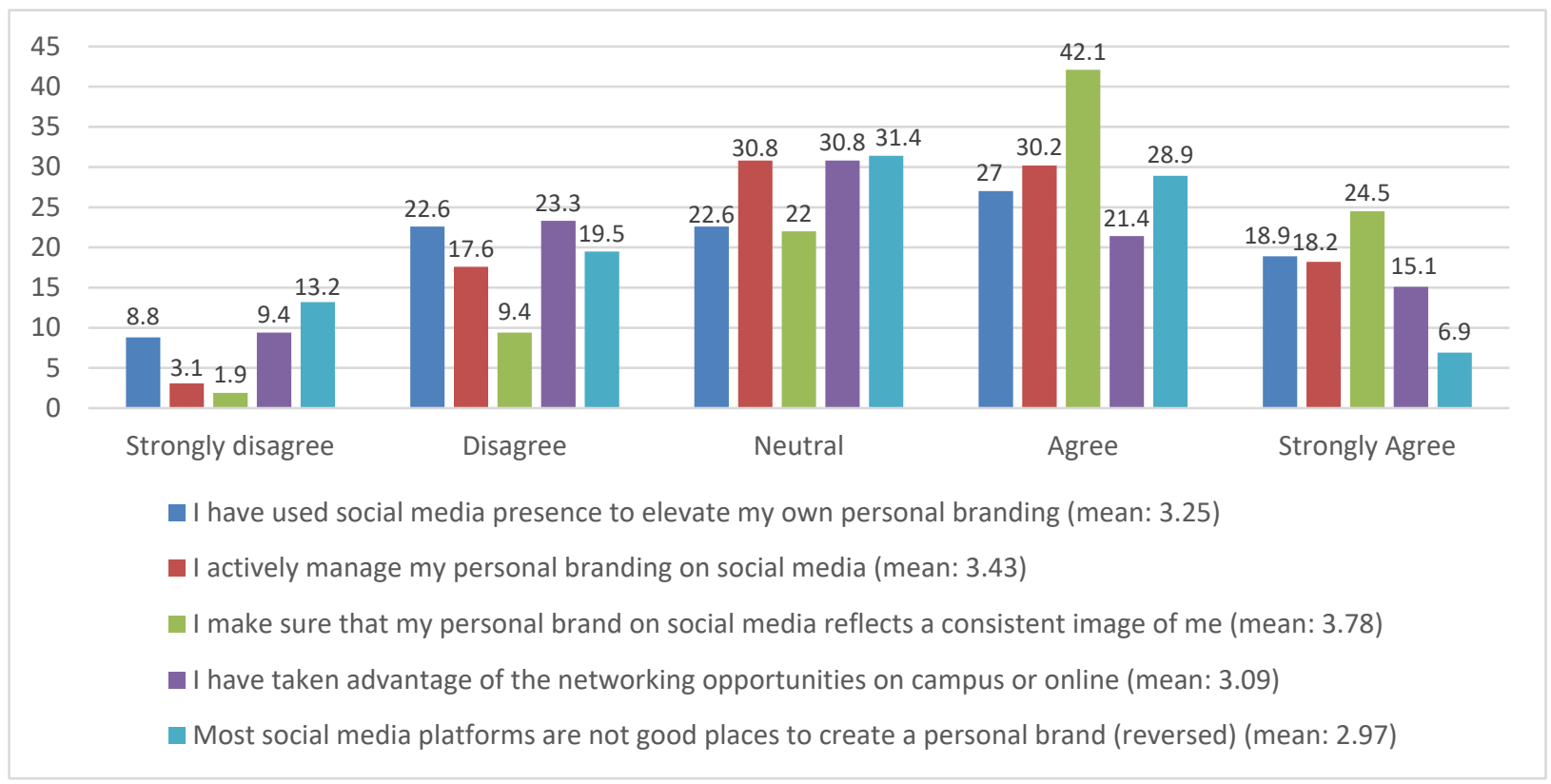

Figure 2 also shows that for three statements that measured the perceptions of students' personal branding efforts in general, the highest agreement was for the statement, "Personal branding is important in regard to my future success" with a mean value of 3.97, followed by "I have worked hard to develop a strong personal brand" with a mean value of 3.60. The third highest mean value for the statement, "I feel that my university is helping me to develop a strong personal brand" was 3.30. Based on the One-sample T-test, all of the mean values of the three statements were significantly higher than the mid-value of 3 at $\mathrm{p}<.01$. Figure 4 shows the valid percents of the agreement levels on a 5-point scale. Overall, the mean values of students' perceptions of their personal branding efforts using social media and in general were between 3 (neutral) and 4 (agree), which also shows there is room for improvement. 


\section{FIGURE 4 \\ STUDENT PERCEPTIONS OF PERSONAL BRANDING EFFORTS IN GENERAL (IN PERCENT)}

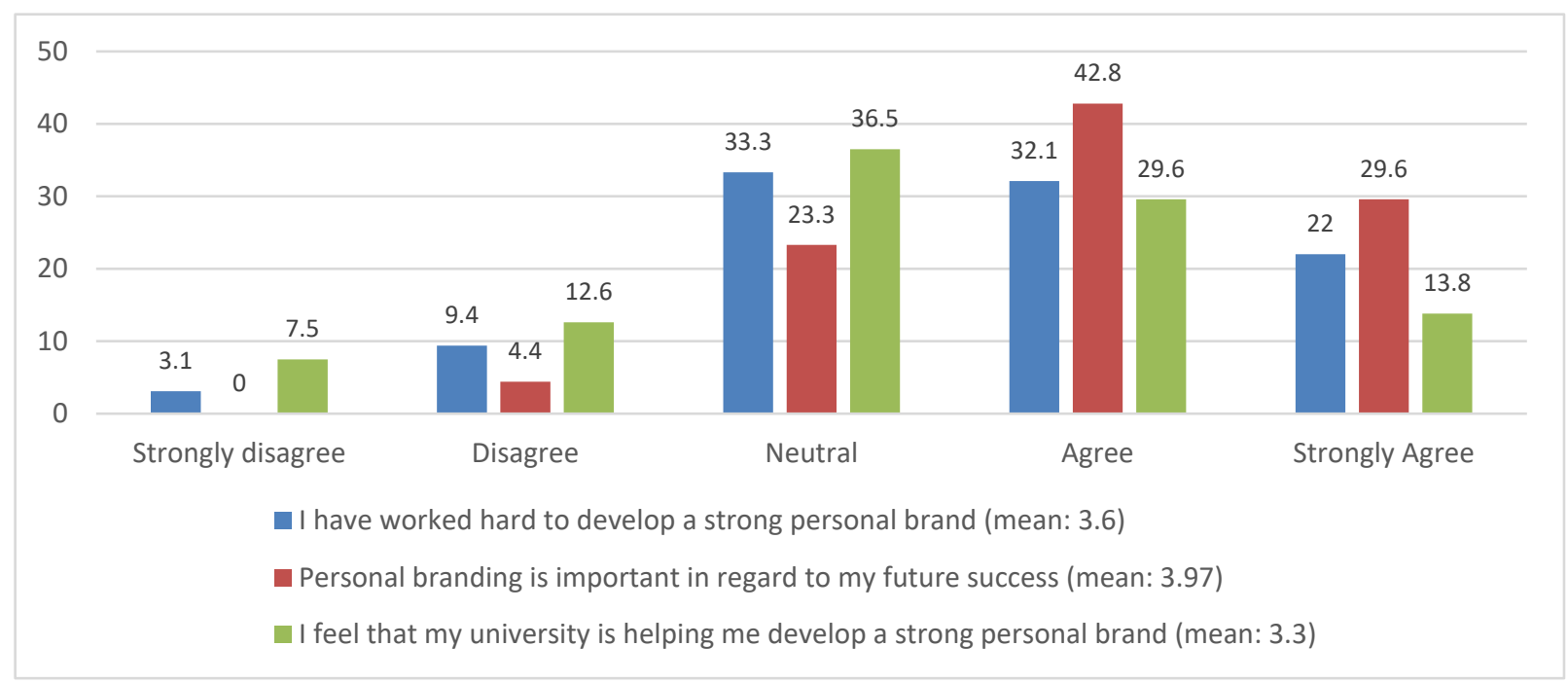

To achieve RO3, differences in the perceptions of students' personal branding efforts based on their use of social media platforms and in general are examined using the Independent-samples T-tests. Table 1 presents the significant differences found between the users and non-users of each social media platform. The users of Instagram, Facebook, and Twitter perceived their personal branding efforts significantly higher than the non-users of these social media platforms at $\mathrm{p}<.01$ and $\mathrm{p}<.05$ levels. The perceptions of students' personal branding efforts did not differ between the users and non-users for Pinterest, LinkedIn, and other social media types. The only exception was that the LinkedIn users perceived themselves significantly working harder to develop a strong personal brand than the non-users at $\mathrm{p}<.01$ level.

TABLE 1

DIFFERENCES IN THE PERCEPTIONS OF PERSONAL BRANDING EFFORTS BY THE USERS AND NON-USERS OF SOCIAL MEDIA

\begin{tabular}{|l|l|l|l|l|c|c|}
\hline Social media & Instagram & LinkedIn & Facebook & Twitter & Pinterest & Other \\
\hline I have used social media & User=110 & N.S. & User=77 & User=59 & N.S. & N.S. \\
presence to elevate my own & Mean:3.62 & & Mean:3.73 & Mean:3.63 & & \\
personal branding & Non- & & Non- & Non- & & \\
& user=49 & & user=82 & user=100 & & \\
& Mean: & & Mean: & Mean: & & \\
& 2.41 & & 2.79 & 3.02 & & \\
& $\mathbf{p}<.01$ & & $\mathbf{p}<.01$ & $\mathbf{p}<.01$ & & \\
\hline I actively manage my personal & User=110 & N.S. & User=77 & User=59 & N.S. & N.S. \\
branding on social media & Mean:3.58 & & Mean:3.65 & Mean:3.69 & & \\
& Non- & & Non- & Non- & & \\
& user=49 & & user=82 & user=100 & & \\
& Mean: & & Mean: & Mean: & & \\
& 3.08 & & 3.22 & 3.27 & & \\
& $\mathbf{p}<.01$ & & $\mathbf{p}<.01$ & $\mathbf{p}<. \mathbf{0 5}$ & & \\
\hline
\end{tabular}




\begin{tabular}{|c|c|c|c|c|c|c|}
\hline $\begin{array}{l}\text { I make sure that my personal } \\
\text { brand on social media reflects } \\
\text { a consistent image of me }\end{array}$ & $\begin{array}{l}\text { User=110 } \\
\text { Mean:4.04 } \\
\text { Non- } \\
\text { user=49 } \\
\text { Mean: } \\
3.20 \\
\text { p<.01 }\end{array}$ & N.S. & $\begin{array}{l}\text { User=77 } \\
\text { Mean:4.00 } \\
\text { Non- } \\
\text { user=82 } \\
\text { Mean: } \\
3.57 \\
\text { p<.01 }\end{array}$ & $\begin{array}{l}\text { User=59 } \\
\text { Mean:3.98 } \\
\text { Non- } \\
\text { user=100 } \\
\text { Mean: } \\
3.66 \\
\text { p }<.05\end{array}$ & N.S. & N.S. \\
\hline $\begin{array}{l}\text { I have taken advantage of the } \\
\text { networking opportunities on } \\
\text { campus or online }\end{array}$ & $\begin{array}{l}\text { User }=110 \\
\text { Mean:3.46 } \\
\text { Non- } \\
\text { user=49 } \\
\text { Mean: } \\
2.27 \\
\text { p }<.01\end{array}$ & N.S. & $\begin{array}{l}\text { User=77 } \\
\text { Mean:3.52 } \\
\text { Non- } \\
\text { user=82 } \\
\text { Mean:2.70 } \\
\mathbf{p}<. \mathbf{0 1}\end{array}$ & $\begin{array}{l}\text { User }=59 \\
\text { Mean:3.58 } \\
\text { Non- } \\
\text { user=100 } \\
\text { Mean: } \\
2.81 \\
\mathbf{p}<.01\end{array}$ & N.S. & N.S. \\
\hline $\begin{array}{l}\text { Most social media platforms } \\
\text { are not good places to create a } \\
\text { personal brand }\end{array}$ & N.S. & N.S. & N.S. & N.S. & N.S. & N.S. \\
\hline $\begin{array}{l}\text { Personal branding is important } \\
\text { in regard to my future success }\end{array}$ & $\begin{array}{l}\text { User=110 } \\
\text { Mean:4.10 } \\
\text { Non- } \\
\text { user=49 } \\
\text { Mean: } \\
3.69 \\
\mathbf{p}<\mathbf{0 1}\end{array}$ & N.S. & N.S. & $\begin{array}{l}\text { User=59 } \\
\text { Mean:4.17 } \\
\text { Non- } \\
\text { user=100 } \\
\text { Mean: } \\
3.86 \\
\text { p<.05 }\end{array}$ & N.S. & N.S. \\
\hline $\begin{array}{l}\text { I have worked hard to develop } \\
\text { a strong personal brand }\end{array}$ & $\begin{array}{l}\text { User=110 } \\
\text { Mean:3.81 } \\
\text { Non- } \\
\text { user=49 } \\
\text { Mean: } \\
3.14 \\
\text { p }<.01\end{array}$ & $\begin{array}{l}\text { User=99 } \\
\text { Mean:3.28 } \\
\text { Non- } \\
\text { user=60 } \\
\text { Mean:3.18 } \\
\mathbf{p}<. \mathbf{0 1}\end{array}$ & $\begin{array}{l}\text { User=77 } \\
\text { Mean:3.88 } \\
\text { Non- } \\
\text { user=82 } \\
\text { Mean:3.34 } \\
\mathbf{p}<. \mathbf{0 1}\end{array}$ & $\begin{array}{l}\text { User }=59 \\
\text { Mean:3.83 } \\
\text { Non- } \\
\text { user=100 } \\
\text { Mean: } \\
3.47 \\
\text { p }<.05\end{array}$ & N.S. & N.S. \\
\hline $\begin{array}{l}\text { I feel that my university is } \\
\text { helping me to develop a strong } \\
\text { personal brand }\end{array}$ & $\begin{array}{l}\text { User=110 } \\
\text { Mean:3.45 } \\
\text { Non- } \\
\text { user=49 } \\
\text { Mean: } \\
2.94 \\
\mathbf{p}<\mathbf{0 1}\end{array}$ & N.S. & $\begin{array}{l}\text { User=77 } \\
\text { Mean:3.56 } \\
\text { Non- } \\
\text { user=82 } \\
\text { Mean:3.05 } \\
\mathbf{p}<.01\end{array}$ & $\begin{array}{l}\text { User=59 } \\
\text { Mean:3.73 } \\
\text { Non- } \\
\text { user=100 } \\
\text { Mean: } \\
3.04 \\
\mathbf{p}<.01\end{array}$ & N.S. & N.S. \\
\hline
\end{tabular}

To determine if various personal branding efforts are impacted by student demographics (RO4), an Independent-samples t-test for gender, and an ANOVA test for class standing were performed. The results showed that the perceptions of males were significantly higher for "Personal branding is important in regard to my future success" than females at $p<.05$ level. In addition, international students perceived "I have taken advantage of the networking opportunities on campus or online" significantly higher than the domestic students at $\mathrm{p}<.01$ level. The perceptions of the students of two universities also did not differ in their perceptions of personal branding efforts using social media and in general.

The One-way ANOVA results revealed no differences in the perceptions of student personal branding efforts based on social media efforts and effects in general across the class levels. This means freshman, sophomore, junior, and senior students perceive their social media efforts for building their personal brand at the same level. 
For RO5, the differences in the use of the social media platforms based on demographics were examined using Crosstabs in SPSS. Significant Chi-square results revealed that female students used Facebook $(60.5 \%)$ and Pinterest (80.6\%) significantly more than male students at $\mathrm{p}<.05$ and $\mathrm{p}<.01$ levels, respectively. In addition, significant Chi-square results were found across class levels and the use of social media platforms. Seniors $(55.1 \%)$ used LinkedIn significantly more than juniors $(24.5 \%)$, and freshman and sophomore combined $(20.4 \%)$ at $\mathrm{p}<.01$ level. Freshman and sophomore students combined used other social media sites like WeChat, SnapChat, TikTok (61.1\%) more than seniors $(38.9 \%)$ at $\mathrm{p}<.05$ level.

\section{DISCUSSIONS AND IMPLICATIONS}

This study aims to provide insights about the student perceptions of their social media use in helping them build their personal brand and the role and use of various social media platforms for building students' personal brands. The results in Figure 1 indicate that Instagram is the most used social media platform by students for building their personal brand, followed by LinkedIn, Facebook, Twitter, and Pinterest. It is somewhat surprising to see that Instagram, instead of LinkedIn, is the most used social media platform for developing a personal brand because LinkedIn positions itself as a professional and career related platform. Nevertheless, the findings suggest that companies may consider the most used social media platforms when they are recruiting.

Concerning the perceptions of students' personal branding efforts through the use of social media, students have the most agreement on making sure that their personal brand reflects a "consistent image" on social media (Figure 2). The consistency in the findings is important and in line with the fundamentals of creating a strong brand (Aaker, 1991, 1996; Keller, 1993, 2013). The second highest agreement indicates that students believe they actively manage their personal branding on social media. This is also supported by the third highest agreement on their perception of using social media presence to elevate their own personal branding. These findings are consistent with prior research emphasizing the importance of students' efforts in building their social media presence and actively managing their profiles (Kleppinger and Cain, 2015). Nevertheless, students must minimize negative image by avoiding controversial photos, poor grammar (LeBlanc, 2018), and inappropriate language.

Regarding students' perceptions of their general efforts for personal branding, the results in Figure 2 show that students are aware of the importance of personal branding for their future success, as indicated by highest mean value of 3.97, with most responses to this item being in "agree or strongly agree" category (Figure 4). This perception is supported by the finding that students perceive they are working hard to develop their personal brand with the mean value of 3.60. These findings verify that students comprehend and are cognizant of the importance of having a strong personal brand, and they seem to be working toward building their personal brand. They also feel that their university is helping them to develop a strong personal brand even though the mean value of 3.30. However, the mean values less than 4 also indicate that students feel there are rooms for improvement.

As for students' personal branding efforts and their use of social media platforms for developing their personal brand, as shown in Table 1, there were significant differences between the users and non-users of Instagram, Facebook, and Twitter platforms for most of the personal branding efforts at $p<.01$ and $p<.05$ levels. The differences indicate that the users of these social media platforms emphasize the relevance of these efforts for building a strong personal brand. The non-significant differences between users and nonusers of LinkedIn, Pinterest and other social media platforms indicate that they equally value these platforms for developing their personal brand. The exception is that LinkedIn users have a significantly

higher perception that they have worked hard to develop a strong personal brand than the non-users of LinkedIn. The findings reveal that social media platforms are used by students who are interested in creating a strong personal brand.

In addressing RO4, the study found significant differences between male and female students' perceptions for only one of the personal branding efforts. More specifically, the males' agreement level on the statement, "Personal branding is important in regard to my future success" was significantly higher than the females. This may imply that males are more interested in developing their personal brand for future 
success than females. In addition, international students perceived that they have taken advantage of the networking opportunities on campus or online significantly higher than the domestic students. Students of two universities did not differ in the perceptions of their social media and general personal branding efforts. Furthermore, the comparisons of the branding efforts by class levels revealed no significant differences in the perceptions of their branding efforts. The findings suggest that regardless of gender, domestic or international, and class levels, students seem to have similar efforts with a few exceptions in developing their personal brand. Finally, concerning the relationships between the social media platforms and student demographics, the study found that significantly more females than males use Facebook and Pinterest, and more seniors use LinkedIn than juniors, sophomores, and freshmen.

The implications of the findings are: 1) The majority of the students use Instagram and LinkedIn social media platforms in developing their personal brand, followed by Facebook and Twitter. In this regard, companies may use the social media platforms when recruiting; however, the type of posts Gen $\mathrm{Z}$ users are posting may differ in their personal branding efforts for different social media audience. In addition, the findings indicate that students do not perceive LinkedIn as the top platform for professional and career development as intended and positioned to be. The LinkedIn managers should explore why LinkedIn is not the top platform among Gen Z. 2) The social media specific and general personal branding efforts indicate that students are highly interested in developing a strong personal brand although our findings show that they do not perceive that they are maximizing their efforts. In developing their personal brands, the users of Instagram and Facebook seem to have higher efforts than non-users. 3) All students, regardless of their gender, class level and domestic or international status, seem to exert similar efforts, with a few exceptions, in developing their personal brand. 4) The study also found that more females are using Facebook and Pinterest, and more seniors are using LinkedIn. This suggests that LinkedIn seems having some difficulties targeting and convincing the college students, especially females, freshmen, sophomore, and juniors for the potential benefits for professional and career development, and networking. 5) Students perceive that their universities are helping them in developing their personal brands. However, given the above findings, universities can take more active role in helping their students in becoming strong brands. This could be a Win/Win strategy for both students and universities because students would be able get their dream jobs as suggested by Gujarathiu and Kulkarni (2018), and universities could attract more and higher quality students.

Moreover, as students build their personal brands, they need to keep in mind that transparency and authenticity are essential efforts for a strong personal brand, which requires consistency with their personal brand identity (Kaplan and Haenlin, 2010; Ward and Yates 2013). Another major factor that students must understand is that creating a personal brand requires credibility (Gujarathi and Kulkarni, 2018), which is necessary to succeed in social networking efforts (Harris and Rae, 2011).

\section{LIMITATIONS AND SUGGESTIONS FOR FUTURE RESEARCH}

This study provides new insights about students' use of social media and their efforts for developing a strong personal brand. However, it has limitations to be considered when interpreting the findings. First, the study was conducted with students at two universities located in the United States. Future studies can benefit from including students from other universities in the U.S. as well as in other countries for crosscultural comparisons. Second, the study used a convenience sample of students. Future studies may benefit from using a probability random sampling method to increase the generalizability of the findings. Third, the study presents only the students' perspectives. Future studies may include faculty members, university administrators, alumni, and companies/recruiters to provide a more holistic understanding of using social media in developing strong student brands. Finally, the study focused on the role of social media in building a student personal brand. Future studies may examine not only what students post on each social media site for different audiences but also the extent of their use of personal web sites, blogs, and other digital content creation tools in building personal brands. 


\section{REFERENCES}

Aaker, D. (1991). Managing Brand Equity. Free-Press, New York, NY.

Aaker, D. (1996). Building Strong Brands. Free-Press, New York, NY.

Arai, A., Ko, Y., \& Kaplanidou, K. (2013). Athlete brand image: Scale development and model test. European Sport Management Quarterly, 13(4), 383-403.

Burnison, G. (2018). Lose the resume: Land the job. Hoboken, NJ: John Wiley \& Sons.

Castrillon, C. (2019, February 12). Why personal branding is more important than ever. Forbes. Retrieved from https://www.forbes.com/sites/carolinecastrillon/2019/02/12/why-personalbranding-is-more-important-than-ever/?sh=1b7481142408

Churchill, G., Jr., \& Iacobucci, D. (2005). Marketing Research: Methodological Foundations (9th ed.). Thomson/South-Western, Mason, OH.

Gershon, I. (2014). Selling yourself in the United States. PoLAR: Political and Legal Anthropology Review, 37(2), 281-295. Retrieved from http://onlinelibrary.wiley.com.libproxy.eku.edu/doi/10.1111/plar.12075/pdf

Girard, T., Pinar, M., \& Lysiak, L. (2020). Understanding Student Perceptions of their Personal Branding in Higher Education. Journal of Higher Education Theory and Practice (JHETP), 20(13), 136146. ISSN: 2158-3595

Gorbatov, S., Khapova, S.N., \& Lysova, E.I. (2018). Personal Branding: Interdisciplinary Systematic Review and Research Agenda. Frontiers in Psychology, 9, 1-17. https://doi.org/10.3389/fpsyg.2018.02238

Gujarathi, R., \& Kulkarni, S. (2018). Understanding personal branding perceptions through intentions. Journal of Management Research, 10(2), 207-217.

Harris, L., \& Rae, A. (2011). Building a personal brand through social networking. Journal of Business Strategy, 32(5), 14-21. https://doi.org/10.1108/02756661111165435

Henderson, G. (2019, November 7). What is personal branding? Retrieved from https://www.digitalmarketing.org/blog/what-is-personal-branding

Hood, K.M., Robles, M., \& Hopkins, C.D. (2014). Personal branding and social media for students in today's competitive job market. The Journal of Research in Business Education, LVI(2), 33-47.

Ilies, V.I. (2018). Strategic personal branding for students and young professionals. Cross-Cultural Management Journal, XX(1), 43-51.

Kaplan, A.M., \& Haenlin, M. (2010). Users of the world unite! The challenges and opportunities of social media. Business Horizons, 53(1), 58-68.

Keller, K. (1993). Conceptualizing, measuring and managing customer-based brand-equity. Journal of Marketing, 57(1), 1-22.

Khedher, M. (2015). A brand for everyone: Guidelines for personal brand managing. The Journal of Global Business Issues, 9(1), 19-27.

Kleppinger, C.A., \& Cain, J. (2015). Personal digital branding as a professional asset in the digital age. American Journal of Pharmaceutical Education, 79(6), 1-4. Doi:10.5688/ajpe79679

Korach, L. (2015, July). What employers really look for in recent college graduates. USA Today College. Retrieved October 16, 2020, from http://college.usatoday.com/2015/07/22/hiring-recent-collegegraduates/

Kucharska, W. (2017). Consumer social network brand identification and personal branding. How do social network users choose among brand sites? Cogent Business \& Management, 4. Retrieved from https://www.tandfonline.com/doi/full/10.1080/23311975.2017.1315879

Kucharska, W., \& Confente, I. (2017). Selfie and personal phenomena in the content of the network economy. A literature Review. Handel Wewnetrzny, 6(371), 161-169.

Labrecque, L.I., Markos, E., \& Milne, G.R. (2011). Online personal branding: Processes, challenges, and implications. Journal of Interactive Marketing, 25, 37-50. Doi: 10.1016/j.intmar.2010.09.002 
LeBlanc, K. (2018). How students can build their personal brand while in university. Retrieved January 7, 2021, from https://medium.com/the-mission/how-students-can-build-their-personal-brandwhile-in-university-50303e21c1e0

Manai, A., \& Holmlund, M. (2014). Self-marketing brand skills for business students. Marketing Intelligence \& Planning, 33(5), 749-762.

McCabe, M.B. (2017). Social media marketing strategies for career advancement: An analysis of LinkedIn. Journal of Business and Behavioral Sciences, 29(1), 85-99.

McCorckle, D., \& Payan, J. (2017). Using Twitter in the marketing and advertising classroom to develop skills for social media marketing and personal branding. Journal of Advertising Education, 21(1), $33-44$.

Morris, T. (2009). All a Twitter: A personal and professional guide to social networking with Twitter. Que ( $1^{\text {st }}$ Edition $)$, pp. 1-312. ISBN: 9780768694178

NACE. (2018, February 19). Are college graduates “career ready?”. Retrieved October 15, 2020, from https://www.naceweb.org/career-readiness/competencies/are-college-graduates-career-ready/

Ollington, N., Gibb, J., \& Harcourt, M. (2013). Online social networks: An emergent recruiter tool for attracting and screening. Personnel Review, 42(3), 248-265.

Parrott, P. (2019). Rich pictures in qualitative research in higher education: The student as consumer and producer in personal branding. International Journal of Work-Integrated Learning, 20(2), 171187.

Poeppelman, T., \& Blacksmith, N. (2014). Personal branding via social media: Increasing SIOP visibility one member at a time. TIP: The Industrial-Organizational Psychologist, 51(3), 112-119.

Rampersad, H.K. (2008). A New Blueprint for Powerful and Authentic Personal Branding. Performance Improvement, 47(8), 34-37.

Rein, I., Kotler, P., Hamlin, M., \& Stoller, M. (2005). High visibility: Transforming your personal and professional brand. McGraw-Hill.

Ries, A., \& Trout, J. (1986). Positioning: The Battle for Your Mind. New York: McGraw-Hill.

Sihi, D., \& Lawson, K. (2018). Marketing leaders and social media: Blending personal and professional identities. Journal of Marketing Theory and Practice, 26(1-2), 38-54.

Spencer, J. (2020). Why building a personal brand is more important than ever. Retrieved January 7 , 2021, from_https://www.entrepreneur.com/article/354437

Vitelar, A. (2019). Like me: Generation $\mathrm{Z}$ and the use of social media for personal branding. Management Dynamics in the Knowledge Economy, 7(2), 257-268.

Ward, C., \& Yates, D. (2013). Personal branding and e-professionalism. Journal of Service Science, 6(1), 101-104.

Wilson, J.S., \& Blumenthal, I. (2008). Managing brand you: Seven steps to creating your most successful self. New York: AMACOM.

YPulse. (2020, May 6). Gen Z \& Millennial's 5 favorite social media platforms now. Retrieved from https://www.ypulse.com/article/2020/05/06/gen-Z-millennials-5-favorite-social-media-platformsnow/ 